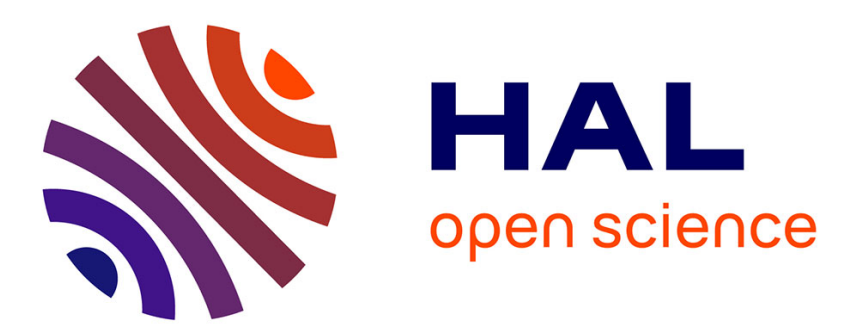

\title{
Standardization Bodies, Initiatives and their relation to Green IT focused on the Data Centre Side
}

\author{
Christina Herzog
}

\section{To cite this version:}

Christina Herzog. Standardization Bodies, Initiatives and their relation to Green IT focused on the Data Centre Side. European Conference Energy Efficiency in Large Scale Distributed Systems (EELSDS 2013), Apr 2013, Vienna, Austria. pp. 289-299. hal-01231770

\author{
HAL Id: hal-01231770 \\ https://hal.science/hal-01231770
}

Submitted on 20 Nov 2015

HAL is a multi-disciplinary open access archive for the deposit and dissemination of scientific research documents, whether they are published or not. The documents may come from teaching and research institutions in France or abroad, or from public or private research centers.
L'archive ouverte pluridisciplinaire HAL, est destinée au dépôt et à la diffusion de documents scientifiques de niveau recherche, publiés ou non, émanant des établissements d'enseignement et de recherche français ou étrangers, des laboratoires publics ou privés. 


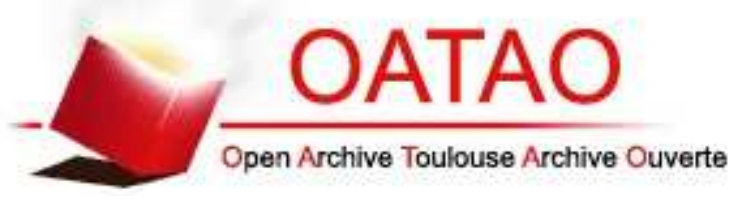

\section{Open Archive TOULOUSE Archive Ouverte (OATAO)}

OATAO is an open access repository that collects the work of Toulouse researchers and makes it freely available over the web where possible.

This is an author-deposited version published in : http://oatao.univ-toulouse.fr/ Eprints ID : 12574

The contribution was presented at EE-LSDS 2013 :

http://www.cost804.org/

Official URL: http://dx.doi.org/10.1007/978-3-642-40517-4_24

To cite this version : Herzog, Christina Standardization Bodies, Initiatives and their relation to Green IT focused on the Data Centre Side. (2013) In: European Conference Energy Efficiency in Large Scale Distributed Systems (EE-LSDS 2013), 22 April 2013 - 24 April 2013 (Vienna, Austria).

Any correspondance concerning this service should be sent to the repository administrator: staff-oatao@listes-diff.inp-toulouse.fr 


\title{
Standardization Bodies, Initiatives and Their Relation to Green IT Focused on the Data Centre Side
}

\author{
Christina Herzog $(\bowtie)$ \\ IRIT, University of Toulouse, Toulouse, France \\ Herzog@irit.fr
}

\begin{abstract}
The aim of this paper is to provide an overview of the main relevant standardization bodies and organizations (national, international, industry groups, standards bodies and regulators) as well as projects, initiatives and actual standards in the field of Green IT, and more especially in the Data Centre area. The co-operation between these different organisations and their different point of views and working areas are also investigated. A critical analysis concerning the motivations and approaches of academia and industry towards the various standardization bodies and initiatives is given.
\end{abstract}

Keywords: Standardization - Regulation - Metrics - Technical committee · Green IT

\section{Introduction}

Standardisation is an important part in the field of Green IT as currently the society is consuming too much energy, and common agreements are missing. There are several organisations - international and national - working on standardization in Green IT but still common outputs are not influencing strongly enough the decision makers. A common classification of energy users is missing. This classification would lead to energy savings as international laws may be voted and penalties applied for those being not energy efficient enough. For instance, new data centres will only be constructed if they have a certain classification, old data centres may have to be renovated or pay a fee based on a certified metric. Before doing such a classification (which is beyond the scope of this paper) it is needed to understand the scope of these standardisation bodies and to identify several organisations involved in standardisation activities, both formal and informal. This includes governmental, industry-related and lobbying groups.

It is indeed more important to investigate the various motivations, the reasons of the actors being involved in standardization bodies. In particular the differences in the approaches from the academia's and industries' point of view may play an important part in the cooperation and in the - existing or not existing - standards. Obviously, one of the motivations for the industry in joining a group is to promote their own technology to become a future standard, but other motivations can also be analyzed. 
The rest of the article is organized as follows: Section 2 will define the standard bodies, Sect. 3 talks about the existing standards, Sect. 4 focuses on Data Centres, Sect. 5 puts some critical arguments on the current situation and analyzes the motivations. Section 6 concludes the paper.

\section{Standards Bodies Defined}

The concept of standardisation is a flexible term when applied to (Green) IT innovation. There are strictly managed standards existing (such as those managed by the International Organisation for Standardisation (ISO), the International Telecommunications Union (ITU) and the International Electrotechnical Commission (IEC) as well as a wide variety of other de facto initiatives, metrics and frameworks being also classified as (non strictly) standards. Legislation plays also a role in the development of common approaches to (Green) IT and its initiatives should also be considered as important.

There is also a wider concept of standardisation, not governed by any overarching organisation but may be defined as how interoperable a particular technology is with the pervasive technologies in a particular market.

There are a variety of classes of initiative that can be categorised as a de facto or actual standard (metrics, frameworks, projects). These various classes of standard types are also administered by a range of different organisations from formal government-backed groups, professional bodies, and principally supplier-led organisations.

Table 1 shows standard body types, their nature of standards and is giving some examples. The standard body type section shows which kind of body it is, who can join, while the second colon what these bodies are providing, how they are structured and what they can provide for the standardization and in the last colon you find some examples of bodies, organisations, initiatives and an example of an EC project, which can also be considered has having influence in the standardization of energy saving.

To help understand the links between the different stakeholders, the Fig. 1 is giving an overview.

On Fig. 1, we can see that the first providers of materials and tools that may make their way to actual standards are industry alliances, academic researchers, or both in

Table 1. Classification of standards organisations

\begin{tabular}{|c|c|c|}
\hline $\begin{array}{c}\text { Standard (de facto or actual) } \\
\text { body type }\end{array}$ & Nature of standards & Example \\
\hline $\begin{array}{c}\text { International, regional and na- } \\
\text { tional and government-backed } \\
\text { standards bodies }\end{array}$ & $\begin{array}{c}\text { Highly structured standards, re- } \\
\text { quiring some degree of certifica- } \\
\text { tion/enforcement }\end{array}$ & $\begin{array}{c}\text { ISO, UN ITU, IEC, } \\
\text { CENELEC-CEN, ETSI }\end{array}$ \\
\hline Institutes and professional bodies & $\begin{array}{c}\text { Structured and de-facto frame- } \\
\text { works, metrics, and projects. } \\
\text { Some certification required }\end{array}$ & $\begin{array}{c}\text { BCS, IEEE, ASHRAE, Uptime } \\
\text { Institute }\end{array}$ \\
\hline Supplier and industry groups & $\begin{array}{c}\text { De-facto standards, projects and } \\
\text { other initiatives. }\end{array}$ & $\begin{array}{c}\text { The Green Grid, Open Compute } \\
\text { Project }\end{array}$ \\
\hline $\begin{array}{c}\text { Technical initiatives, projects, } \\
\text { supplier product development, }\end{array}$ & $\begin{array}{c}\text { Loosely structured initiatives, } \\
\text { published research etc. }\end{array}$ & EC projects: e.g. CoolEmall \\
\hline
\end{tabular}




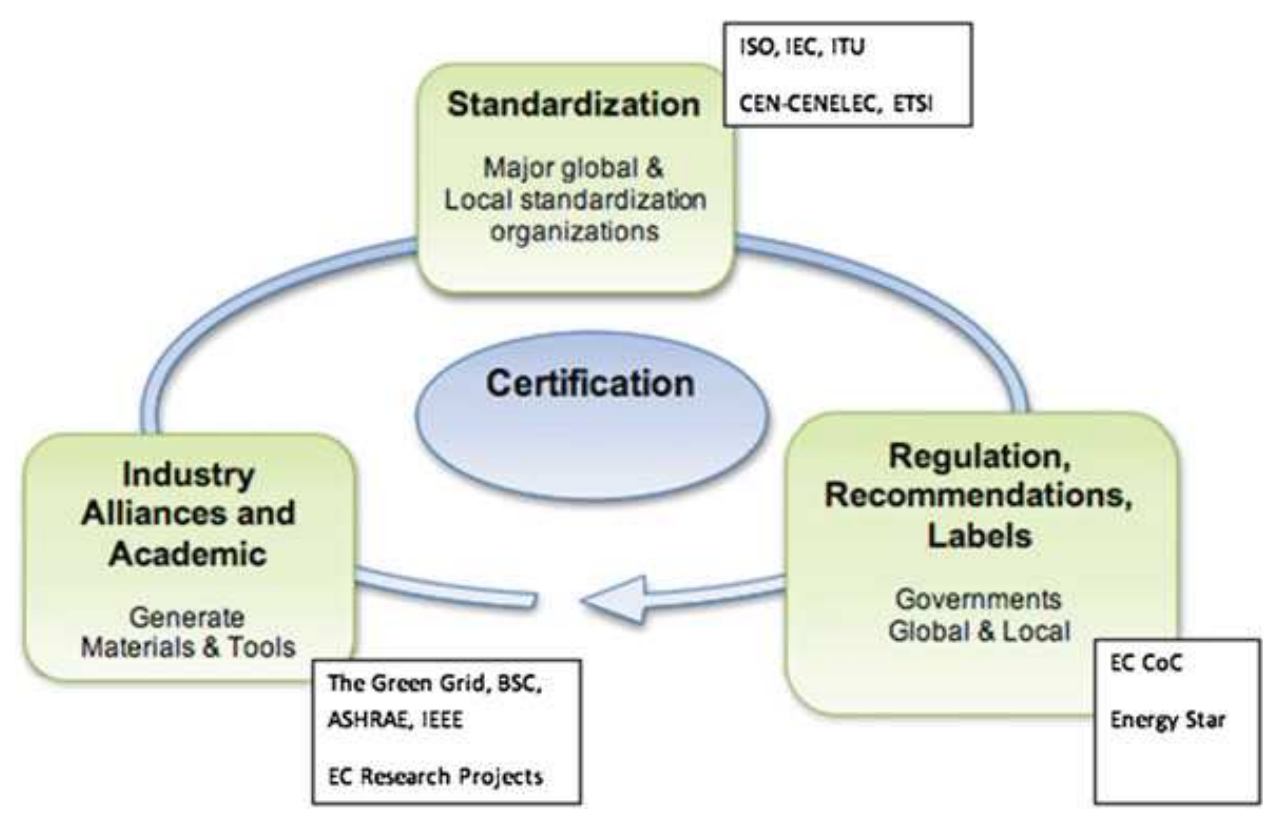

Fig. 1. Existing links between standardization stakeholders

collaborative projects. Some of the proposed ideas may be presented in one or several standardization bodies to eventually become standards. These standards can in turn be used by governments (national, federal or European levels) as regulations in laws that must (and can) be enforced.

Direct usage of the materials can also be used directly by governments as regulations, recommendations or labels. While the process for formal standardization make take long since a consensus have to be achieved between all members (especially states), the direct link with governments is sometimes more efficient.

Finally, it must be noted that some materials provided by the industry and academic are used directly by final users and may become de facto standards.

In the centre of the Figure is the certification authority whose role is to certify that the measurements, claimed by suppliers of technologies follow actually the standards, the labels or the recommendations.

\section{Relevant Sustainability Standards}

Sustainability standards, metrics, frameworks and initiatives affect data centres in multiple ways. Some, such as green building certifications, allow data centres to voluntarily demonstrate a certain level of environmental performance. For instance BRE Global proposed a new standard for data centres building. Other standards, such as American Society of Heating Refrigeration and Air-conditioning (ASHRAE)'s temperature standards, can carry the force of de-facto mandates, or form the basis for true mandates later. Sustainability standards can affect how strongly data centres demand efficiency technologies, and sometimes even which technologies they choose. There are standards that address both IT and data centre facilities. Industrial bodies, professional groups develop and propose some standards. When a large community accepts these, they can be promoted to national and international standardization 
bodies, as it is at the moment discussed for the PUE (Power Usage Effectiveness) standard [6]. Government can use these defined standards to enforce regulations, as for instance for the operation of data centres with the Data Centre Code of Conduct of the European Union (voluntary based at the moment) that could form a base for a law in the future.

Several international and governmental standard bodies have been created. These groups are not always only related to IT but there is a level cooperation between different bodies and there appears to be progress in the international standardisation in the sector of IT.

ISO is made up of numerous country-specific standards bodies. Inside ISO, Technical Committee TC207 is interested in environmental management. IEC is particularly interested in the electro-technical field: Therefore their impact on Green IT cannot be ignored. Technical Committee TC111 has the responsibility of environmental standardization aspects. Like ISO, IEC is built on national standard bodies. A Joint initiative between IEC and ISO (JTC1/SC39) is investigating together Green IT.

ITU has developed standards, not only but mainly in the telecommunication sector, and is therefore also influencing the IT. ITU is built on direct national influence (members are nations, not national bodies like for ISO and IEC). In ITU, Study Group 5 is in charge of environmental aspects.

Altogether, these three bodies develop International Standards that are fully consensus-based and represent the needs of key stakeholders of every nation participating in these bodies. Every member country (or national body) has one vote and a say in what goes into an International Standard. Members come from all around the world. While each member is different, they do have one thing in common: all of them represent the entire range of interests in and for their country, companies and businesses, industry associations, educational bodies, governmental and regulatory bodies. All stakeholders are brought together through the country's member National Committee.

It should be noted that the most active members of these committees are mainly coming from the private sector, so their standards are recommendations and have to be seen in a critical way as private companies may want to push their technology in order to be number one on the market.

Generally it can be said that there is an overlap between these different groups coming from different areas. The positive aspect is that these different groups may have some overlap in defining standards, they may have the same direction of e.g.: saving energy, the difficulty might be that there are too many organizations, initiatives existing and that the exchange between is not smoothly, sometimes information are even not published and of course it is easy to lose the overview of activities in different initiatives.

\section{Links Between the Standardization Bodies Related to Energy Efficiency in Data Centres}

Joint Technical Committees are established between ISO and IEC in specific areas. For instance, JTC 1/SC 39 is the joint sub-committee on "Sustainability for and by Information Technology". The focus is on standardization related to the intersection 
of resource efficiency and Information Technology, which supports sustainable development, application, operation and management aspects, is investigated. Especially the WG 1 is working on data centre energy efficiency. They are responsible for the first drafts of the standard for metrics for assessing the energy efficiency of data centres (the PUE standard at the moment).

The European Commission has established a standardisation mandate. It requests that the three European standards bodies CEN, CENELEC and ETSI develop standards that enable efficient energy use in fixed and mobile information and communication networks.

CEN-CENELEC (European Committee for Electrotechnical Standardisation) embeds Technical Committee 215 on Electrotechnical aspects of telecommunication equipment. The standards produced by TC 215 are used by a variety of customers including planners and installers of information technology cabling and of those facilities containing significant concentrations of information technology equipment (e.g. data centres), manufacturers of cabling systems and associated components as well as test houses. CENELEC has a close cooperation with its international counterpart, the International Electrotechnical Commission (IEC). This close cooperation has resulted in some $76 \%$ of all European standards adopted by CENELEC being identical or based on IEC standards.

ETSI (European Telecommunications Standards Institute) produces globally applicable standards for Information \& Communications Technologies. ETSI performs energy efficiency related work in support of European Commission Mandates.

Looking at a bird eye, concerning European standardization activities on Data Centres: the Network is done by ETSI, the Power infrastructure by CENELEC, the IT management by CEN, the cooling by ASHRAE and the monitoring by CEN/CENELEC. The need for having joint and coordinated groups is therefore obvious. The establishment of the Coordination Group on Green Data Centers (CEN-CENELECETSI) helps to harmonize initiatives. Nevertheless, for researchers in the field, the challenge is big to understand and follow all individual developments.

\subsection{Regulations}

Through initial work such as the Directive on Energy End-Use Efficiency and Energy Services, National Energy Efficiency Action Plans (NEEAPs), the ICT for Energy Efficiency (ICT4EE) Forum, the European Commission is attempting to establish a common and worldwide methodological framework by the whole ICT sector for the measurement of its energy and carbon footprint. For instance, established by the European Commission and parties from the IT industry in 2010, the ICT4EE forum focuses on two key aspects of Eco-efficient IT: first, how the technology industry can curb its energy use; and second, how it can help other sectors do likewise. By mid 2010, four industry associations had signed up to represent the European, Japanese and American ICT industries in the Forum: DigitalEurope; Global e-Sustainability Initiative (GeSI); the Japanese Business Council Europe (JBCE); and TechAmerica Europe. Works may one day lead to worldwide regulations. 
The European Code of Conduct on Data Centres Energy Efficiency has been developed in response to the increase in energy consumption in data centres and the current needs to decrease the economic, environmental and energy supply security impacts. The aim is to inform and foster the improvement of energy efficiency in the planning and operation of data centres. The Code of Conducts aims to achieve this by raising awareness and recommending energy efficient best practices and targets [3].

The Code of Conduct it is not a legally binding document but a voluntary initiative with the objective of bringing stakeholders together. Parties signing up will be expected to follow this set of best practices recommendations and abide to the principles described therein. The Code contains a comprehensive list of best practices as well as documentary aids and measurement procedures. Data centres may be entitled to use the Code logo if such improvement programs have been certified by appropriated certification authority and recognised by the EU Commission [4]. If the Code of Conduct works well, it could be made mandatory under European law to encourage energy efficiency among non-participants; conversely, if it doesn't produce results, the European Commission might seek a tougher approach.

Energy Star program started in 1992 by the US EPA (Environment Protection Agency, www.energystar.org). Since 2009 only, specifications for servers are available, and in early 2013 active state, performance reporting were added, together with blade and multi-node servers idle requirements. These steps are very important in the case of data centres since these technologies are now days at the core of their operation. While being only a label and raising a lot of controversial issues on its delivery, it has the advantage of being now worldwide known and applied.

As we can see, no real regulations exist today and no standards made its way to a formal regulation that could be enforced by law with incentives or penalties applied.

\subsection{Industry Groups and Professional Bodies}

Writing a report about standardisation there is also the need to take the institutes and professional bodies, groups of parties, into account and to investigate more deeply about their activities and their influence on the on-going research and on the society. These groups differ in several dimensions: Some are country based, others are at European or global levels; some are activated by governments while others are industry or professional based; some provides standards, others certifications.

The Green Grid is a non-profit, open industry consortium of IT suppliers, endusers, policy-makers, technology providers, facility architects, and utility companies. The aim is to promote the agenda of these suppliers but also unite global industry efforts, create a common set of metrics, and develop technical resources and educational tools. The Green Grid has expanded its mission from "energy efficient IT" to "resource efficient IT," meaning that it will begin looking at water, carbon, materials, waste, in addition to just energy. It is linked to the global ecosystem of technical organisations and government institutions: The American Society of Heating, Refrigerating and Air-Conditioning Engineers (ASHRAE), The British Computer Society BCS-The Chartered Institute for IT, China Communications Standards Association (CCSA). 
The Green Grid has developed a number of metrics, frameworks and initiatives in the domain of Data Center Energy Efficiency: PUE, WUE, and CUE, to name a few. These metrics assess the quality of a data centre in terms of efficiency of the resource provided against the resources useful for the IT equipment. The PUE metric is also used in the European Code of Conduct $(\mathrm{CoC})$. Many data centre service providers now report that customers are asking PUE numbers in procurement documents. It should be stressed that there is no regulatory agency that monitors or certifies PUE ratings, and therefore the figures, widely cited, have no legal status, and are prone to distortion by technical and marketing staff [5].

However, we can note that two task forces, namely the Data Center Metrics Coordination Task Force (U.S. Regional Task Force) and the Global Harmonization of Data Center Efficiency Metrics Task Force (Global Task Force), have affirmed PUE as the agreed-upon metric for measuring infrastructure energy efficiency in data centres. These task forces are composed of industry players and government agencies, from US and Japan. In a published memo, the Data Center Metrics Coordination Task Force not only affirms agreement for PUE, it also provides recommended calculation and reporting guidelines for PUE.

It can be noted the PUE metric is currently being proposed for standardisation at the ISO level (a process that should be completed in approximately two years). Altogether from the first mentioned to this metric in 2007, it will take about 8 years to become a standard, which is an eternity in the timeline of data centres developments.

Started in 2007, Climate Savers Computing Initiative (CSCI) is a non-profit group of consumers, businesses, and conservation organisations dedicated to reducing the energy use and CO2 emissions from computers. In 2012, it became part of Green Grid. Computer and component manufacturers participate in Climate Savers by committing to make products that meet or exceed current ENERGY STAR standards. Consumers and corporations participate by committing to choose PCs and volume servers that meet or exceed the standards, and to use power management features. CSCI's "baseline" efficiency standards for PCs and servers are based on the respective ENERGY STAR standards for PCs and servers. Higher levels of CSCI certification (Bronze, Silver, Gold) add additional requirements regarding power supply efficiency. At the electronic level, the EPEAT (Electronic Product Environmental Assessment Tools) has the same objective, i.e. to help identify greener computers and electronic equipments.

The Uptime Institute (UI) provides education, publications, consulting, certifications, conferences and seminars, independent research, and thought leadership for the enterprise data centre industry and for data centre professionals.

The British Computer Society has a number of initiatives - particularly through its Data Centre Specialist Group (DCSG). In collaboration with the UK Carbon Trust, the BCS DCSG developed open source software that can be used to model energy efficiency and carbon emissions in data centres on a per-service basis (leading and transferred to the commercial Prognose software). The simulation tool has been developed by some of the advisors to the EC on how to measure data centre efficiency. They developed a set of metrics (DC-FVER: Data centre Fixed to Variable Energy Ratio metric). Although there has been no indication of this, the EC could recommend the use of such metrics in a future iteration of the data centre Code of Conduct. 
The American Society of Heating, Refrigerating, and Air-Conditioning Engineers (ASHRAE) is an influential standards group whose work impacts data centres in several ways. ASHRAE's guidelines have a significant influence on data centre design and equipment selection, and any changes are inevitably controversial. One set of ASHRAE guidelines describes the temperature and humidity ranges in which data centre computer rooms should operate. Data centres are intended to operate most of the time within ASHRAE's fairly narrow "recommended" temperature and humidity ranges. For limited periods of time, ASHRAE permits IT equipment to venture outside this recommended range into a broader "allowable" range of temperature and humidity conditions. They create new, broader allowable ranges for data centres that wish to aggressively prioritize energy efficiency (at the cost of potentially higher operational risk). The new ASHRAE allowable ranges give additional latitude to data centre operators that wish to maximize use of economizers and "free cooling". Rather than using energy-hungry mechanical cooling systems, economizers allow data centre to use cool outdoor temperatures to meet some or all of the data centre's cooling demand. This flexibility allows data centres to reduce energy use or even design facilities with no mechanical cooling at all ("chiller-less" designs). Although ASHRAE standards do not have the force of law, many jurisdictions adopt them as part of mandatory building codes. Thus, ASHRAE's 90.1 standards strongly affect new data centre construction and major renovations.

The Open Compute Project (OCP) is an initiative from Facebook to build one of the most efficient computing infrastructures at the lowest possible cost. Custom designing, building own software, servers and data centres from the ground up, and finally share those technologies as they evolve is the objective of this project.

Of particular interest are two main aspects:

- Hardware management: Scale computing requires a small and stable set of tools to remotely management machines. The hardware management specification incorporates a set of existing tools and best practices and leverages existing tools for remote machine management.

- The Open Rack is the first rack standard that is designed for data centres, integrating the rack into the data centre infrastructure, part of the Open Compute Project's "grid to gates" philosophy, a holistic design process that considers the interdependence of everything from the power grid to the gates in the chips on each motherboard.

It can be noted that the specifications are free of charge to download, as part of this open source initiative.

\section{Critical Points}

What can be clearly seen is that standardization in IT is a complex system of different components, various organizations, bodies and different points of view but it is quite obvious that there is a growing interest in standardization by universities, industries and governments. Unfortunately the reasons for it are very different and this is also the reason why so many different bodies, organizations and initiatives exist [1]. 
Comparing the different aims, approaches, duties, priorities, ... between industries and universities it is obvious that even if they join the same standardization bodies their interests can't be the same [2].

Table 2 below shows the different interests of academia and industry divided into 3 sections:

- Research and innovation

- Criteria of dissemination

- Organization

Table 2. Similarities and differences of academia and industry

\begin{tabular}{|c|c|c|c|c|}
\hline \multirow{6}{*}{ 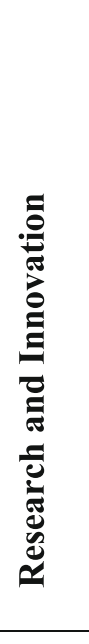 } & & & Academia & Industry \\
\hline & $\mathrm{A}$ & $\begin{array}{l}\text { Duties/ } \\
\text { responsibilities }\end{array}$ & $\begin{array}{l}\text { Common welfare } \\
\text { Extension of knowledge }\end{array}$ & $\begin{array}{l}\text { Profit orientation } \\
\text { Offering service and } \\
\text { prodducts for the market }\end{array}$ \\
\hline & $\mathrm{B}$ & Core competence & $\begin{array}{l}\text { Fundamental research in } \\
\text { Software and Hardware } \\
\text { User oriented research } \\
\text { Experimental research }\end{array}$ & $\begin{array}{l}\text { User oriented research } \\
\text { Experimental research } \\
\text { Product development }\end{array}$ \\
\hline & $\mathrm{C}$ & Approach & Search and find General & Decide and act concretely \\
\hline & $\mathrm{D}$ & Priorities of topics & $\begin{array}{l}\text { Personal interests } \\
\text { Expected appreciation } \\
\text { Financing }\end{array}$ & $\begin{array}{l}\text { Strategic development of the } \\
\text { company } \\
\text { Portfolio of the products }\end{array}$ \\
\hline & $\mathrm{E}$ & Selection of topics & Autonomic funding relevant & $\begin{array}{l}\text { Innovation management } \\
\text { Top management }\end{array}$ \\
\hline \multirow{5}{*}{ 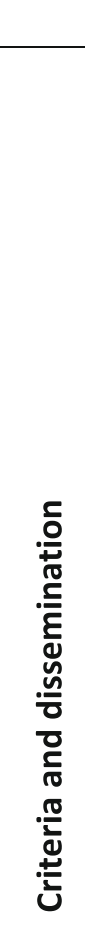 } & & & Academia & Industry \\
\hline & $\mathrm{F}$ & $\begin{array}{l}\text { Criteria of efficien- } \\
\text { cy }\end{array}$ & Scientific reputation & $\begin{array}{l}\text { Profit and company } \\
\text { value }\end{array}$ \\
\hline & $\mathrm{G}$ & $\begin{array}{l}\text { Criteria of quality } \\
\text { of the work }\end{array}$ & $\begin{array}{l}\text { Systematic production } \\
\text { Reconstructable processes and re- } \\
\text { sults } \\
\text { Big application area } \\
\text { Explanatory Contribution }\end{array}$ & $\begin{array}{l}\text { Usability of the results } \\
\text { Big effects for the } \\
\text { clients usage } \\
\text { Advantageous eco- } \\
\text { nomic solution for a } \\
\text { concrete application } \\
\text { area } \\
\text { Production of an inno- } \\
\text { vation leading to a } \\
\text { temporary monopoly } \\
\text { position }\end{array}$ \\
\hline & $\mathrm{H}$ & Reference groups & $\begin{array}{l}\text { Scientific community } \\
\text { Student }\end{array}$ & $\begin{array}{l}\text { Clients } \\
\text { Other units within the } \\
\text { company }\end{array}$ \\
\hline & I & $\begin{array}{l}\text { Distribution of the } \\
\text { results }\end{array}$ & $\begin{array}{l}\text { Conferences } \\
\text { Publications } \\
\text { Patents }\end{array}$ & $\begin{array}{l}\text { Products } \\
\text { Internal processes } \\
\text { Services } \\
\text { Patents }\end{array}$ \\
\hline
\end{tabular}




\begin{tabular}{|c|c|c|c|c|}
\hline \multirow[b]{4}{*}{ 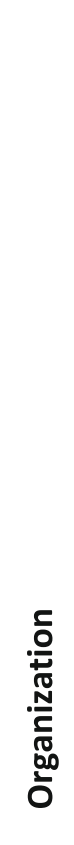 } & $\mathrm{J}$ & Freedom of action & $\begin{array}{l}\text { High } \\
\text { Limited through resources (fund- } \\
\text { ing, staff, equipment, ...) }\end{array}$ & $\begin{array}{l}\text { Average limits } \\
\text { through management }\end{array}$ \\
\hline & $\mathrm{K}$ & Funding & $\begin{array}{l}\text { Non-performance related basic } \\
\text { financing } \\
\text { Calls of funding organizations } \\
\text { Services for companies }\end{array}$ & $\begin{array}{l}\text { Budget of the inno- } \\
\text { vation management } \\
\text { In house accounting }\end{array}$ \\
\hline & $\mathrm{L}$ & $\begin{array}{l}\text { Organizational } \\
\text { framework }\end{array}$ & $\begin{array}{l}\text { Fixed and solid } \\
\text { Influenced through scientific com- } \\
\text { munity } \\
\text { Need safety concerning the ex- } \\
\text { penses }\end{array}$ & $\begin{array}{l}\text { Flexible } \\
\text { Influenced through } \\
\text { market needs, clients' } \\
\text { needs } \\
\text { Searching for informa- } \\
\text { tion about efficiency } \\
\text { and risk }\end{array}$ \\
\hline & M & $\begin{array}{l}\text { Relation with other } \\
\text { units of the organi- } \\
\text { zation }\end{array}$ & $\begin{array}{l}\text { Limited administrative support is } \\
\text { offered } \\
\text { Interaction within a given frame- } \\
\text { work } \\
\text { Parallel units with other fields of } \\
\text { competences }\end{array}$ & $\begin{array}{l}\text { Part of a chain within } \\
\text { the company } \\
\text { Targets given by the } \\
\text { management }\end{array}$ \\
\hline
\end{tabular}

In each of these 3 parts there are different sections and the different approaches, the different interests of academia and industry are shown. It is obvious that in a standardization body where the number of academia and industry partners is equivalent the outcome is more balanced in terms of innovation and interest of the industry. While when the number of industries in a body is leading the recommendations for standards, the outcome might be more business related and less influenced by the latest research.

In the line $\mathrm{C}$ concerning the approach the operating research and development departments in companies prefer simple solutions. Solutions, which are not costly, working immediately and non high-maintenance products are definitely the ideal outcome, the perfect serviceable knowledge. Even if with more investments e.g. measuring the load of servers, or thinking about different methods of cooling the companies could achieve better solutions they keep in mind the profit and the management is setting the priorities - see line E.

This approach is also reflected in the decisions of the standardization bodies and also in the decision which body should the industry join. Often it is the easiest way to do lobbying for the solution, which is provided already by the company, but it might not be the best one for the sustainability.

Line $\mathrm{K}$ shows one of the difficulties for universities as they have a limited budget and often no funding for joining standardization bodies as getting access to documents and meetings is sometimes limited to paying partners. This limits the accessibilities for research institutes and as a result the outcome, the recommendations are not including the latest research.

Due to the differences of industry and academia standardization bodies and organizations are limited in their actions and in producing results, recommendations, which may influence governments or give support for further actions like launching open calls. 


\section{Conclusion}

Having a look on different standardization bodies and organizations it is necessary to investigate more deeply about their structure, their members and their aims. Currently some of the organizations are not accessible easily, and for evaluating their recommendations it is necessary to become a paying or active member. This makes it even more difficult to use their results for e.g. evaluating a data centre or following their recommendations for research. The question which has to be faced is: How can recommendations be followed if there is no background information available? There are so many standardization bodies and influence groups on the market with different aims, often unknown, with different parties involved, but without exchange. Every organisation, every government following the recommendation of one of these bodies has to be aware that there is no outside control, and that these bodies are not necessarily objective organisations.

Acknowledgment. This research work is partly supported by the European Commission under contract 288701 through the project CoolEmAll and by the COST (European Cooperation in Science and Technology) framework, under Action IC0804.

\section{References}

1. Blind, K., Gauch, S.: Trends in ICT standards: the relationship between European standardisation bodies and standards consortia. Telecommun. Policy 32(7), 503-513 (2008), ISSN 0308-5961. Elsevier

2. Jakobs, K., Procter, R., Williams, R.: The making of standards: looking inside the work groups. IEEE Commun. Mag. 39(4), 102-107 (2001)

3. Uddin, M., Rahman, A. A.: Energy Efficiency and low carbon enabler green IT framework for data centers considering green metrics. Renew. Sustain. Energy Rev. 16(6), 4078-4094 (2012)

4. European Commission.: The EU-Code of Conduct on Data Centers Energy Efficiency (2008)

5. Federal Ministry for the Environment, Nature Conservation and Nuclear Safety. EnergyEfficient Data Centers: Best-Practice Examples from Europe, The USA and Asia (2010)

6. Belady, C. (ed.): The Green Grid Data Center Power Efficiency Metrics: PUE and DCIE, The Green Grid, White Paper \#6 (2008) 